\title{
Geoecological problems of civil engineering in the riverside zone (case study of the Volga riverside zone)
}

\author{
Darya Vasilieva $^{1}$, Margarita Baranova ${ }^{1}$, and Yuriy Kholopov ${ }^{2 *}$ \\ ${ }^{1}$ Samara State Technical University, 244 Molodogvardeyskaya St., 443100 Samara, Russia \\ ${ }^{2}$ Samara State Transport University, 2B Svobody St., 443066 Samara, Russia
}

\begin{abstract}
In the context of widespread urbanization an increase in the area of built-up areas is taking place. At the same time land plots previously occupied by industrial enterprises, forest and agricultural land, etc. are used for construction. Development of new territories can lead to the activation of exogenous geological processes and the increase of environmental problems associated with geological hazards (karst, erosion, landslides, subsidence, waterlogging and flooding of land, etc.). The aim of the article is to study the influence of civil construction on the geoecological condition of the territory by the example of the bank zone of the Volga river within the city of Samara.
\end{abstract}

\section{Introduction}

A significant environmental problem of our time is the increasing urbanization, which leads to the growth of both the urban population and the area of urban development. The projected urban population is estimated at 5 billion people by 2030 , with $81 \%$ of the world's urban population in the cities of developing countries [1]. According to statistical reporting for the year 2020, 74.7\% of the population of the Russian Federation live in cities (as of 01.01 .2020 ) [2]. In the process of urbanization, land plots that previously performed other functions, such as agricultural land, forested areas, etc., are involved in economic use. Increasing anthropogenic impact leads to the degradation of natural landscapes, which is especially dangerous in coastal areas, as it leads to the degradation of hydrographic basins, and in general to a decrease in the quality of ecosystem services [3-5]. The deterioration of the ecological condition of the city is contributed by the growth of the urbanized area [6-7]. Preservation of urban coastal areas in the natural state, the development of tourism and recreation in them is a promising direction of sustainable urban development [8].

The aim of the article is to study the coastal zone of the Volga River within the city of Samara and the impact of civil construction on the geo-ecological state of the territory. In order to achieve the goal the following tasks were set: 1) analysis of the results of monitoring and observations of the condition of the bank zone of the Volga River within the Zagorodniy Park of Samara city, and the abandoned quarry on the mountain Tyap-Tyav, which are polygons for summer geological practice for students of construction profiles of

\footnotetext{
* Corresponding author: kholopov@bk.ru
} 
the Academy of Construction and Architecture of Samara State Technical University and Samara State University of Railway Transport; 2) evaluation of the current condition of the bank zone of the Volga River and identification of the most dangerous exogenous geological processes (EGP).

\section{Materials and methods}

Federal State Statistics Service (Rosstat) materials, state (national and regional) reports on the state and use of lands in the Russian Federation and in the Samara region were studied. Materials of territorial planning of Samara city, stated in the General plan and Rules of land use and building were also studied and by means of analysis of remote sensing data the modern condition of the Volga river coastal zone within Samara city limits was investigated.

Territory of Samara city is $541,38 \mathrm{~km}^{2}$ and is situated on the watershed at the place where rivers Samara and Sok join the Volga river. The geographical coordinates of the city are $53^{\circ} 14^{\prime} \mathrm{N}, 50^{\circ} 14^{\prime} \mathrm{E}$. The length of the coastal zone of the city is more than $30 \mathrm{~km}$ on the banks of the Volga River and more than $40 \mathrm{~km}$ on the banks of the Samara River. The coastal zone is a high floodplain and floodplain terraces, moreover, a large part of the floodplain was flooded during the construction in 1967-1968 of the Saratov reservoir. Saratov reservoir on the Volga River. Construction of the reservoir led to raising of water level near the city of Samara by $5.5 \mathrm{~m}$ compared with the low-water level, as well as to a significant reduction in the area of islands and beaches. The left eastern bank of the Volga River, where the old part of Samara city is situated, is relatively low, with absolute marks of 40-50 m. On the territory of Samara city are widely Quaternary alluvial and diluvial deposits, composed of loam, sandy loam, sand and clay [9]. The territory of Samara city is heterogeneous in the geological respect and is characterized by the course of different EGP. At development of new territories for the purpose of civil engineering can occur activation of the given processes and their transformation in geological dangers. The development of EGP is often natural and man-made nature and is associated with climate (freezing and thawing of rocks), biological and hydrogeological factors, gravity (surface water flowing down the slopes), the effect of wind, etc. [10-12].

The most economically developed part of the bank zone of the Volga River within the old part of the city - there are several embankment stages, high density and number of stories of buildings. The shading on the picture shows an area of Sokolh Hills which massif goes along the Volga bank from the mouth of the Sok river to Studenov Gully and then gradually descends to the Postnikov Gully. Here is the most elevated part of the city of Samara. The area of Sokolh Hills includes the Uplenka and Krasnaya Glinka settlements, parts of the city of Samara.

This area is characterized by a pronounced mountainous terrain, which is an eastern extension of the Zhiguli. Sokol Mountains are separated from Zhigulyovo massif by a wide valley of the Volga River. In terms of their shape, the Sokol Mountains are a hilly plateau, in some places extremely rugged with ravines. The highest is the northwestern edge of the massif, abruptly breaking off in the west to the Volga River and in the north - to the Sok River. Some peaks of the Sokol Mountains reach up to 250-280 m absolute height. The highest peak of the Sokol Mountains is Tip-Tyav, which reaches a height of $282 \mathrm{~m}$. The mountains and slopes are covered with suppressed forest vegetation. The Sokol Mountains area is characterized by the following EGPs: karst, suffosion, landslides and gully erosion on the slopes. Landslides are formed on steep coastal slopes. They are formed under the influence of river erosion, slope watering or construction impacts [11-13]. 
There are abandoned quarries for construction minerals on the territory of Falcon Mountains (Fig. 1). The quarry uncovered the thickness of the sedimentary rocks of the Permian period in five ledges, in the form of clear cuts, which are very interesting in geological terms object. The territory of the quarry is currently not reclaimed and is used by local residents for recreation, construction of garages and landfills. At the foot of the quarry benches, karst formation processes in the form of grottoes, physical weathering processes in the form of clumps, accumulation of removal cones of crushed stone, gravel and small fragmentary material are revealed. Most of the quarry is not covered with vegetation, since reclamation was not carried out to a sufficient extent, in addition, there are signs of illegal extraction of building stone.

At present, the territory of Sokolniki Mountain, including the coastal zone, is actively developed mainly for civil construction purposes. The bank zone of the Volga river is the most attractive area for residential development as real estate prices are the highest here. According to the Rules of land use and development of Samara city, mainly here there is a zone of low-rise buildings of individual houses with garden plots, forest areas, natural monuments of regional importance, territories of sanatoriums and resorts, recreation, tourism, sports, as well as projected sites of low-rise construction [14].

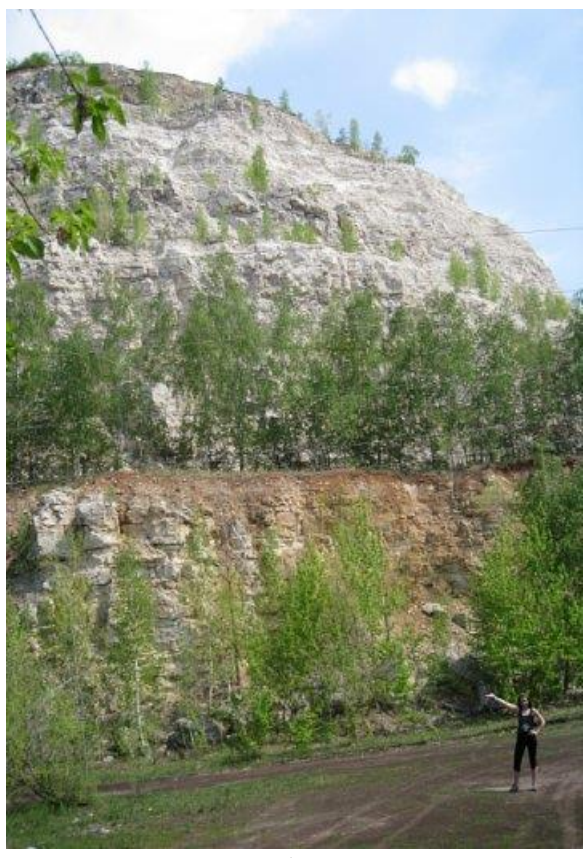

A

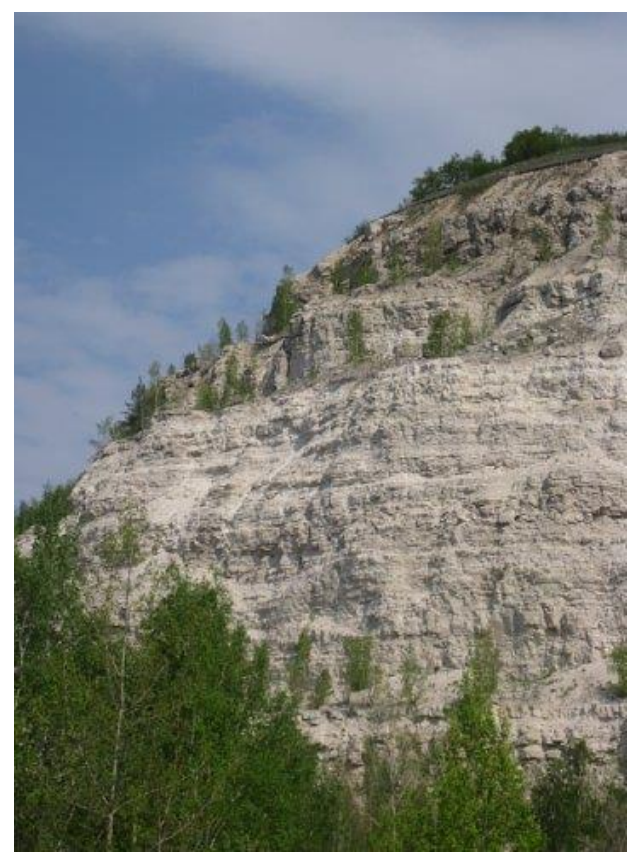

B

Fig. 1. The quarry on Mount Tip-Tyav: A - lower benches with elements of reclamation; B - upper benches

From the surface, the territory is covered with a continuous cover of syrtic and deluvial loams with a thickness of 5 to 25 meters. The underlying rocks on a large area are limestones and, less often, dolomites with gypsum and anhydrite lenses of the Kazan tier of the upper Permian, on a smaller one - red-colored clays of the Tatar tier.

The clay loams, conventionally classified as soddy, in the vast majority are homogeneous, normal, less common are light sandy loam type [15]. There is no permanent aquifer in them. However, in some places, where the loams are heavy, close to clays, they contain groundwater of the "headwater" type. The flow rate of these waters is insignificant, due to the weak water yield of loams. The depth of the mirror of this aquifer is subject to 
considerable fluctuations, but not less than 3-4 meters. Physical-technical properties of soddy loams are characterized by the following data (Table 1). These loams are overlapping strata for karst-prone rocks, so the activity of karst formation depends on the thickness of their layer.

Table 1. Physical and technical properties of cheese loams

\begin{tabular}{cc}
\hline Physical and technical properties & Loams \\
\hline Humidity, \% & 18,75 \\
Degree of humidity & 0,67 \\
Specific gravity, $\mathrm{g} / \mathrm{cm}^{3}$ & 2,71 \\
Volume weight, g/cm & 1,82 \\
Porosity, \% & 43,0 \\
Porosity coefficient & 0,76 \\
Rolling boundary, \% & 17,45 \\
Number of plasticity, \% & 15,0 \\
Design resistance at a depth of $2 \mathrm{~m}, \mathrm{~kg} / \mathrm{cm}^{2}$ & 2,4 \\
\hline
\end{tabular}

In the coastal zone of the Volga River, carbonate rocks in the form of limestone, marl, dolomite, and sulfate that come to the surface or lie close to it were noted within the studied area. The rocks are strongly karsted. The degree of karsting increases from lower to higher hypsometric position of the carbonate strata. The conditions of karst formation are not the same everywhere, as they depend on the depth of the carbonate strata, as well as on the thickness and permeability of the overlying rocks. In those places, where carbonate rocks lie close to the surface and above the level of ground waters, karst processes arise in them due to leaching of rocks with the formation of cavities up to large cavities and caves. With significant sizes of voids under the pressure of the overlying strata collapse and sagging of their roofs occurs. As a result, sinkholes and deflections are formed on the surface [15]. The distribution of karst relief, and the high karst nature of the rocks is an unfavorable factor for construction.

To assess the activity of karst processes, it is appropriate to use such indicators as the features of karst sinkholes and cavities, their number, diameter, and depth (Fig. 2). We noted both old soddy sinkholes, serving as a sign of karst processes in the past, and fresh sinkholes, accompanying the modern process of karst formation. This testifies to the fact that hydrogeological and hydrothermal conditions are changing under the man-made impact. In accordance with the adopted in the Russian Federation state standard [16], the stability of the territory of the bank zone of the Volga River (by the example of the territory of Zagorodny Park) in relation to the average diameters of karst failures has a category B, according to the intensity of failure has category II stability (unstable), karst refers to the sulfate-carbonate type, by time of formation - to modern karst, in relation to groundwater is in the aeration zone [10]. 


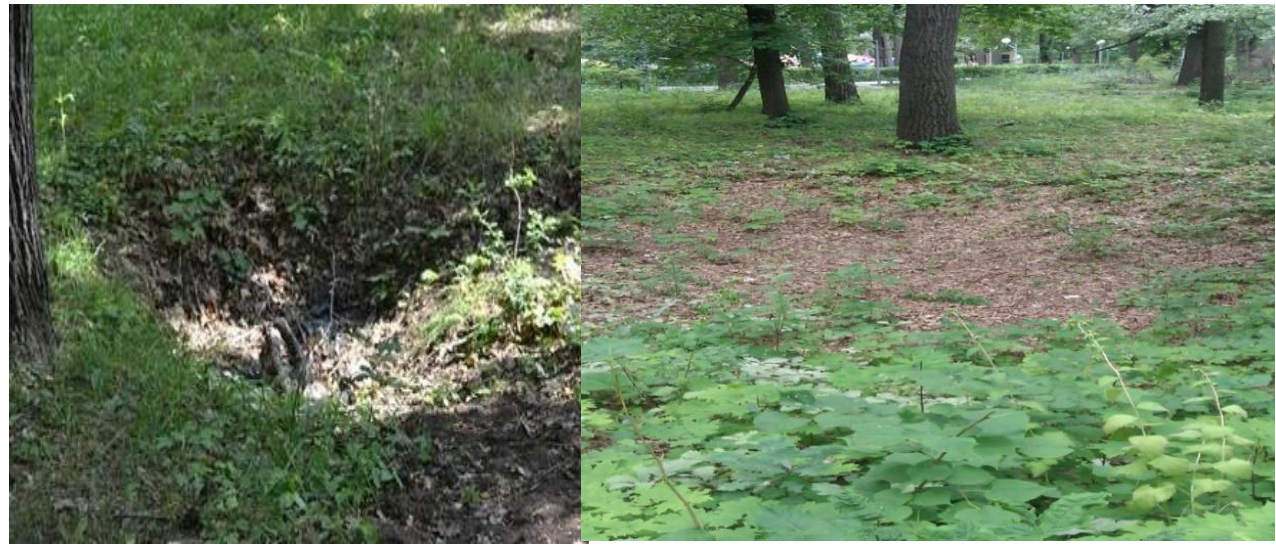

A

B

Fig. 2. Karst sinkholes (A) and sinkholes (B) in the bank zone of the Volga River

In the coastal zone of the Volga River on the slopes of the Sokolii Mountains and above floodplain terraces there are active landslide processes. Landslides are displacement of rock masses down the slope by gravity, and may arise and become active when slopes are overwatered, undermined and undercut, during seismic shocks, etc. A sign of landslides are trees with bent and inclined trunks ("drunken forest") (Fig. 3). According to the direction of inclination of "drunken forest" trunks, you can observe landslide activation on slopes. At present, the observed landslide in the territory of the Suburban Park has stopped its development, which can be seen by young trees with smooth vertical trunks. It is interesting that within a small area, landslide movement in different directions on the slope is observed [10].

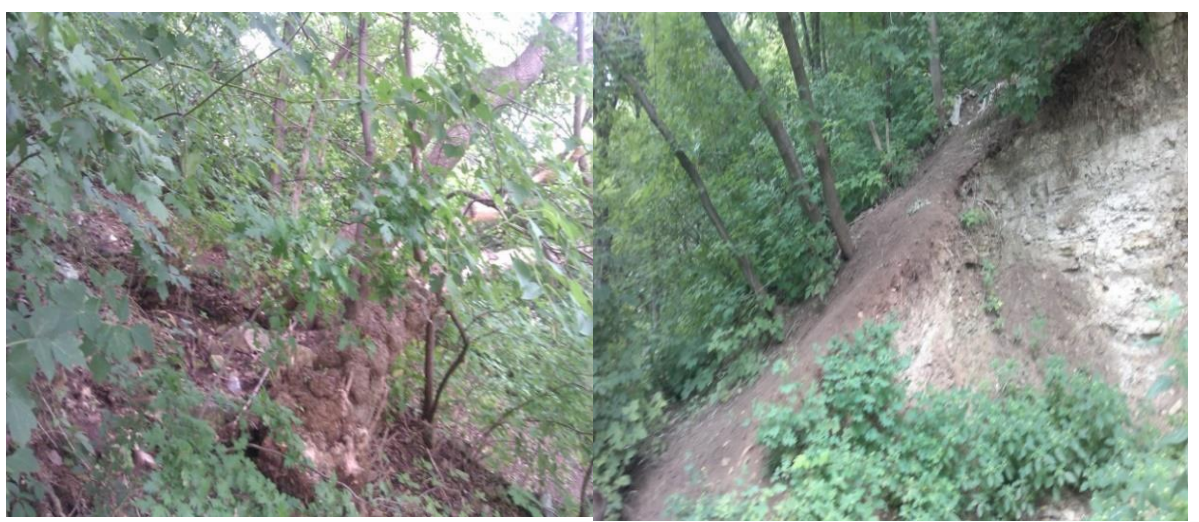

Fig. 3. Landslides on the slopes of the floodplain terrace of the Volga River

Manifestations of gully-erosion processes are confined to the lower part of the slope of the first floodplain terrace and the floodplain area of the Volga river valley. Conditions favorable for gully formation and growth are: presence of easily erodible soils; downpours and rapid spring snowmelt; steep slopes; low erosion base; slope exposure, significant temperature differences leading to formation of cracks in soils and weathering; man-made factors - destruction of vegetation; creation of trenches and furrows on slopes and others.

In the spring period in the coastal zone it is possible to observe processes of flooding of the floodplain by hollow water, when water comes almost to the beginning of the slope of the first terrace above the floodplain. Flooding in the floodplain area is characteristic 
throughout the year because groundwater lies closer than $3 \mathrm{~m}$ from the day surface [17]. The negative impact on economic objects is manifested in the watering of foundations, the appearance of water in basements, etc., which can cause deformation of buildings and structures.

\section{Results and discussions}

Manifestations of gully-erosion processes are confined to the lower part of the slope of the first floodplain terrace and the floodplain part of the Volga River valley. Conditions favorable for formation and growth of gullies are: presence of easily erodible soils; heavy rains and rapid spring snowmelt; steep slopes; low base of erosion; exposition of slopes, significant temperature variations leading to formation of cracks in soils and weathering; technogenic factors - destruction of vegetation; creation of trenches and furrows on slopes and others.

In the spring period in the coastal zone it is possible to observe the processes of flooding of the floodplain by hollow water, when the water comes almost to the beginning of the slope of the first terrace above the floodplain. Flooding of the floodplain area is characteristic throughout the year, as groundwater lies closer than $3 \mathrm{~m}$ from the daily surface [17]. The negative impact on economic objects is manifested in the flooding of foundations, the appearance of water in basements, etc., which can cause deformation of buildings and structures.

\section{Conclusions}

As a result of the study the following conclusions can be made: 1) long-term monitoring of the course of EGP on the territory of the Volga River bank zone (by the example of the territory of Zagorodny park) showed high activity and annual increase depending on conditions of atmospheric moistening and the level of technogenic load; 2) the current state of the bank zone is characterized by significant anthropogenic load, which negatively affects the state of flora and fauna and leads to increased impact on geological environment; 3) the territory of the Volga River bank zone is a unique natural object Unorganized construction, deforestation and change of this territory land use will lead not only to the deterioration of the city environment but also to the activation of exogenous geological processes here.

\section{References}

1. V. V. Mishchenko, I. V. Mishchenko, Urban agglomerations: formation and prospects for development (on the example of Barnaul agglomeration). Contours of global transformations: politics, economy, 5(37) (2015) https://cyberleninka.ru

2. Federal State Statistics Service, https://rosstat.gov.ru

3. R. P. Campos, R. C. Nunes de Oliveira, A. P. Veról, A. N. Haddad, M. G. Miguez, Science of The Total Environment, 777, 145907 (2021)

4. C. Vert, G. Carrasco-Turigas, W. Zijlema, A. Espinosa, L. Cano-Riu, L. R. Elliott, J. Litt, M. J. Nieuwenhuijsen, M. Gascon, Landscape and Urban Planning, 190, 103611 (2019)

5. Z. Wang, M. Xu, H. Lin, S. Qureshi, A. Cao, Y. Ma, Journal of Cleaner Production, 279, $123422(2021)$

6. Q. Ma, Y. Li, L. Xu, Journal of Cleaner Production, 300, 126945 (2021) 
7. U. Somorowska, M. Łaszewski, Science of The Total Environment, 656, 458 (2019)

8. P. Fan, Z. Ouyang, D. D. Nguyen, T. T. Hang Nguyen, H. Park, J. Chen, Landscape and Urban Planning, 187, 145 (2019)

9. M. N. Baranova, A. V. Maltsev, D. I. Vasilieva, Urban Planning and Architecture., 7(2(27)), 9 (2017)

10. D. I. Vasilieva, I. P. Shimanchik, M. N. Baranova, Traditions and innovations in construction and architecture. Construction, 394 (Samara State Technical University. Samara, 2019)

11. V. M. Kutepov, A. I. Sheko, Natural Hazards of Russia. Exogenous geological hazards, 348 (Moscow: Publishing Company KRUK, 2002)

12. D. Vasilieva, A. Maltsev and M. Baranova, XXIX R-P-S Seminar 2020 IOP Conf. Series: Materials Science and Engineering, 1015, 012057 (IOP Publishing, 2021)

13. D. I. Vasilieva, M. N. Baranova, A. V. Maltsev, S. V. Sokolova, Urban Planning and Architecture, 10(4(41)), 4 (2020)

14. Land use and development rules for the Samara urban district, https://www.samadm.ru

15. V. I. Rachitsky, Collection Geology, geochemistry and exploitation of oil fields (Kuibyshev: KPTI, 1969)

16. The Code of Rules. SP 116.13330.2012. Engineering protection of territories, buildings and structures from dangerous geological processes. Basic principles. https://docs.cntd.ru

17. The Code of Rules. SP 104.13330.2016. Engineering protection of the area against flooding and waterlogging. https://docs.cntd.ru 